\title{
Effect of Integrated Marketing Communication on Brand Equity (Case Study of Toyota Calya Cars In Pt. Hasjrat Abadi Gorontalo Branch).
}

\author{
Yudi Hamdani, Edy Prihantoro \\ Faculty of Magister Management, Gunadarma University, Depok, West Java, Indonesia
}

\begin{abstract}
Article Info

Volume 7, Issue 4

Page Number: 96-103

Publication Issue :

July-August-2020

\section{Article History}

Accepted : 20 July 2020

The effective and efficient application of Integrated Marketing Communication can play an important role in efforts to increase sales. The study was conducted to determine the effect of Integrated Marketing Communication variables such as Advertising, Sales Promotion, Events or Events and Public Relations on Brand Equity of Toyota Calya cars at PT. Hasjrat Abadi Gorontalo Branch. This research used the non-probability sampling method of incendental sampling by distributing questionnaires to 110 respondents using direct forms and Google Drive. Respondents namely consumers of PT. Hasjrat Abadi Gorontalo Branch who bought LCGC cars. The results of this study indicate that sales promotions, events and public relations conducted by companies have a positive and significant effect on brand equity.
\end{abstract}

Published : 25 July 2020
Keywords: Integrated marketing communication, Brand equity, Low-cost cars

\section{INTRODUCTION}

To meet the public's need for cheap family cars, the Government of Indonesia through the Ministry of Industry has issued a policy on the cheap car program (LCGC) as stipulated in Government Regulation (PP) No.41 of 2013 concerning Taxable Goods classified as Luxury in the form of Motorized Vehicles subject to Sales Tax on Luxury Goods and Regulation of the Minister of Industry No.33 / M-IND / PER / 7/2013 concerning the Development of Energy-Saving and Affordable Four-Wheeled Motorized Vehicle Production. Therefore, car manufacturers in Indonesia are competing to make Low Cost Green Car (LCGC) types in supporting the Indonesian government's policy to meet and enliven the automotive market share, especially in this LCGC car class.

The effective and efficient application of Integrated Marketing Communication can play an important role in efforts to increase sales. The study was conducted to determine the effect of Integrated Marketing Communication variables such as Advertising, Sales Promotion, Events or Events and Public Relations on Brand Equity of Toyota Calya cars at PT. Hasjrat Abadi Gorontalo Branch. 


\section{LITERATURE REVIEW}

Kotler and Keller (2016) define marketing as "marketing is an organizational function and a set of processes for creating, communicating, and delivering value to customers and for managing customer relationships in ways that benefit the organization and its stakeholders".

Kotler and Armstrong (2016) "marketing mix is the set of tactical marketing tools that the firm blends to produce the response it wants in the target market". Namely the marketing mix is a set of marketing tools that companies use to get responses in a target market.

George Belch \& Michael Belch (2012) Marketing communication as a concept that aims to add value to a comprehensive plan that is able to evaluate the strategic role of various communication tools, with the aim of providing clarity of consistency and the impact of optimal communication. For example: advertising, direct marketing, sales promotion, public relations and combining these promotional tools to provide an explanation of the consistency and maximize the impact of communication

Lili Adi and Donni Juni (2017) Integrated Marketing Communication is a process of developing and implementing various forms of persuasive communication programs to customers and prospective customers on an ongoing basis. The purpose of integrated marketing communication is to influence or provide a direct effect on the behavior of the target audience they have.

Kotler and Keller (2016), brand equity is the added value given to products and services. Brand Equity can be reflected in the way consumers think, feel, and act in relation to the brand, and also the price, market share, and profitability that the brand provides for the company.
Aaker \& Biel (2013) asserts that brand image is the main driver of brand equity. Every expectation of premium cash flow enjoyed by a successful brand depends ultimately on consumer behavior and consumer behavior driven by the perception of a brand. Brand image forms the basis for making better strategic marketing decisions about how to target market segments and position products. Managers try to find, choose, maintain, and support a positive and unique brand image.

\section{METHODS}

The object of research is the sale of Toyota Calya cars in the period January to December 2019. The research subjects are consumers of PT. Hasjrat Abadi Gorontalo Branch to find out the influence of Integrated Marketing Communication variables such as Advertising, Sales Promotion, Events and Public Relations to the Equity of the Toyota Calya car brand at PT. Hasjrat Abadi Gorontalo Branch.

\section{Population and Sample}

The population in this study are consumers of PT. Hasjrat Abadi Gorontalo Branch. Consumers are examined to see the business side of the company's business both from Integrated Marketing Communication and Brand Equity conducted by PT Hasjrat Abadi Gorontalo Branch. In this study the samples taken were consumers of PT. Hasjrat Abadi Gorontalo Branch who has bought and used a Toyota Calya car at PT. Hasjrat Abadi Gorontalo branch. Because of the limited time and information, researchers only conduct research in one company.

Sampling to consumers PT. Hasjrat Abadi Gorontalo Branch is done by giving questionnaires to respondents. With non probability sampling, the incidental sampling method, the sampling process is based on coincidence, that is, anyone who carries a 
Toyota Calya car at the garage of PT. Hasjrat Abadi Gorontalo Branch who met with researchers can be used as a sample.

The research sample point 1 strongly disagrees, point 2 disagrees, point 3 is not agree, point 4 agrees and point 5 strongly agrees.

\section{Research Model and Variabel}

The concept of descriptive and verification approach, because of the variables to be examined in their relationship and the aim to present a structured, factual, picture of the facts of the relationship between the variables examined. The author tries to explain the relationship between variables, Integrated Marketing Communication (X), which affect the Brand Equity $(\mathrm{Y})$ variable.

\section{Data Analysis Tool}

The method used in this research is descriptive analysis, multiple linear regression analysis and to test the hypothesis using the $\mathrm{F}$ test to determine the effect of the independent variables together on the dependent variable and use the $\mathrm{T}$ test to determine the effect of partially independent variables on the dependent variable.

This method is called quantitative method because the research data in the form of numbers and analysis using statistics. Data processing is performed using a computerized Microsoft Excel program and the SPSS 20 for Windows program

Validity test is the accuracy between the data collected and the data that actually occurs on the object under study. The test technique used is the correlation technique through the product moment correlation coefficient. The ordinal score of each question item whose validity is tested is correlated with the overall item's ordinal score.
Reliability test is a test used for adjust the accuracy of a measure or a reliability gauge. A measure or a reliable measurement must have high reliability. Test Reliability shows an understanding that the instrument can be sufficient trusted to be used as a data collection tool, because it is an instrument it's good.

\section{RESULTS AND DISCUSSION}

Before discussing the results of the study, it will first be discussed regarding the characteristics of respondents. Characteristics of respondents are divided by gender, age, education, type of work and monthly expenditure level. Respondent profiles can define useful targets so that PT. Hasjrat Abadi Gorontalo Branch. In this study the distribution of questionnaires was conducted on 110 respondents who used Toyota Calya car products in the city of Gorontalo. Following the division of respondents based on the characteristics that have been determined. Researchers distributed questionnaire forms to consumers who used Toyota Calya PT. Hasjrat Abadi Gorontalo Branch and distributing questionnaires on Google Drive via WhatsApp.

\section{Profile of Respondens Base on Gender}

The results of the questionnaire collection have been done, it can be seen that the number of male respondents was 66 respondents and female respondents were 44 respondents.

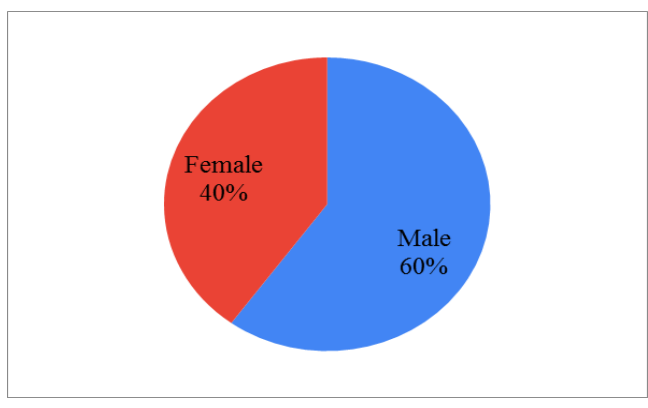

Figure 1. Consumer Profile by Gender 


\section{Profile of Respondens Base on Age}

Based on the results of questionnaire collection, it can be seen that from 110 respondents there were 11 respondents aged between 20 to 30 years, 71 respondents aged between 30 to 40 years and 28 respondents aged between 40 to 50 years. It can be concluded that most respondents who responded to the questionnaire were aged 30 to 40 years with 71 respondents.

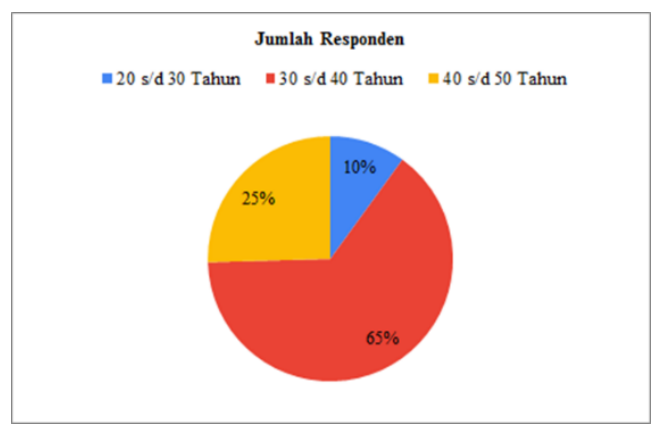

Figure 2. Consumer Profile by Age

\section{Profile of Respondens Base on Education}

Based on the results of the questionnaire collection, it can be seen that from 110 respondents there were 9 respondents who had high school education, 25 respondents who had a diploma education, 65 respondents who had a scholars education, 8 respondents who had a post graduates education and 3 respondents who had a doctors education. Then it can be concluded that most respondents who responded to the questionnaire who had scholars education were 65 respondents.

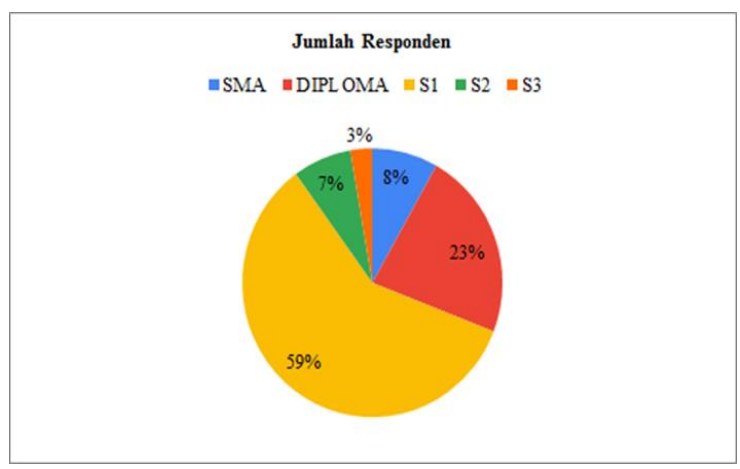

Figure 3. Consumer Profile by Education

\section{Profile of Respondens Base on Job Type}

As a result of the questionnaire collection that has been done, it can be seen that as many as 71 respondents work as private employees, 8 respondents work as entrepreneurs, 10 respondents work as traders, 9 respondents work as State Civil Apparatus (ASN), 3 respondents work as TNI / PORLI, 1 respondent works as an Expert and 8 respondents work as Others. From these results, it can be concluded that most respondents who responded to the questionnaire had a private employee job.

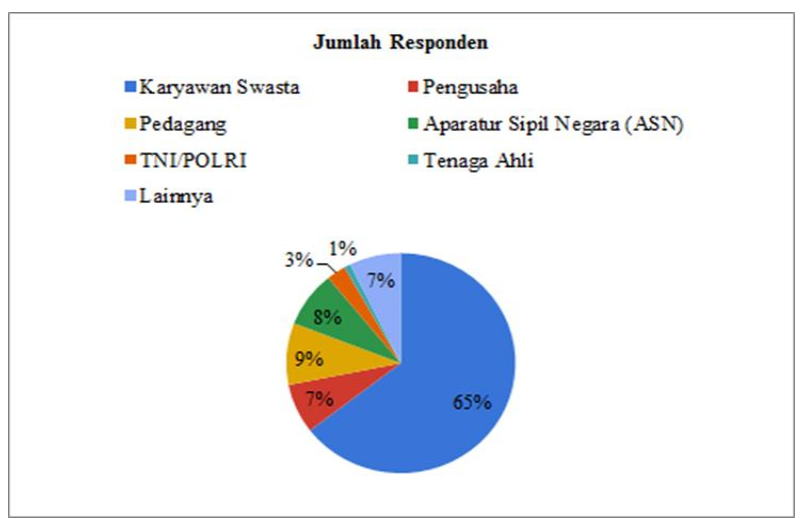

Figure 4. Consumer Profile on Job Type

\section{Profile of Respondens Base on Monthly Expenditures}

As a result of the questionnaire collection that has been done, it can be seen that as many as 7 respondents have expenditures of 2 million per month, 35 respondents have expenditures between 3 million to 5 million per month, 44 respondents have expenditures between 6 million to 10 million per month and 24 respondents have expenses above 10 million. From these results, it can be concluded that most respondents who responded to the questionnaire had a monthly expenditure of between 6 million and 10 million per month.

\section{Chi-Square Tests}

The Relationship of Advertising with Brand Equity 


\begin{tabular}{|c|c|c|c|}
\hline \multicolumn{4}{|c|}{ Chi-Square Tests } \\
\hline & Value & df & $\begin{array}{c}\text { Asymp. Sig. } \\
\text { (2-sided) }\end{array}$ \\
\hline Pearson Chi-Square & $8,648^{2}$ & 6 &, 194 \\
\hline Likelihood Ratio & 8,871 & 6 & ,181 \\
\hline Linear-by-Linear & 470 & 1 & \\
\hline Association & $4, / 24$ & 1 &, 050 \\
\hline N of Valid Cases & 110 & & \\
\hline
\end{tabular}

it can be concluded that the value of Asymp.Sig. shows the probability value $0.194>0.05$ so that the ad has a negative relationship with brand equity. This means that advertising does not affect the brand equity of a product. Therefore PT. Hasjrat Abadi Gorontalo Branch must be more effective and efficient in using advertisements to increase sales of Toyota Calya car products.

\section{The Relationship of Sales Promotion with Brand} Equity

\begin{tabular}{|l|c|c|c|}
\hline & Value & df & $\begin{array}{c}\text { Asymp. Sig. } \\
\text { (2-sided) }\end{array}$ \\
\hline Pearson Chi-Square & $93,441^{2}$ & 10 &, 000 \\
Likelihood Ratio & 96,294 & 10 &, 000 \\
Linear-by-Linear & 61,119 & 1 &, 000 \\
Association & 110 & & \\
N of Valid Cases & \\
a. 9 cells (50,0\%) have expected count less than 5. The \\
minimum expected count is, 25.
\end{tabular}

it can be concluded that the value of Asymp.Sig. shows the probability value of $0,000<0.05$ so that the sales promotion has a positive relationship with brand equity. The importance of sales promotion has a positive impact on the brand equity of a product. Sales promotion conducted by PT. Hasjrat Abadi Gorontalo Branch has been effective and efficient in increasing sales of Toyota Calya car products.

\section{The Relationship of Event with Brand Equity}

\begin{tabular}{|l|c|c|c|}
\hline & Value & df & $\begin{array}{c}\text { Asymp. Sig. } \\
(2 \text {-sided })\end{array}$ \\
\hline Pearson Chi-Square & $85,445^{2}$ & 12 &, 000 \\
Likelihood Ratio & 78,257 & 12 &, 000 \\
Linear-by-Linear & 49,083 & 1 &, 000 \\
Association & 110 & & \\
N of Valid Cases & a. 12 cells (57,1\%) have expected count less than 5. The \\
minimum expected count is,25.
\end{tabular}
-

it can be concluded that the value of Asymp.Sig. shows the probability value of $0,000<0.05$ so that the event has a positive relationship with brand equity. This means that sales promotions positively affect the brand equity of a product. Sales promotion conducted by PT. Hasjrat Abadi Gorontalo Branch has been effective and efficient in increasing sales of Toyota Calya car products.

\section{The Relationship between Public Relations and Brand Equity}

\begin{tabular}{|l|c|c|c|}
\hline & Calue & Df & $\begin{array}{c}\text { Asymp. Sig. } \\
(2 \text {-sided) }\end{array}$ \\
\hline $\begin{array}{l}\text { Pearson Chi-Square } \\
\text { Likelihood Ratio } \\
\text { Linear-by-Linear }\end{array}$ & $48,075^{2}$ & 4 &, 000 \\
Association & 40,585 & 4 &, 000 \\
N of Valid Cases & 110 & 1 &, 000 \\
a. 2 cells (22,2\%) have expected count less than 5. The \\
minimum expected count is 3,44.
\end{tabular}

it can be concluded that the value of Asymp.Sig. shows the probability value of $0,000<0.05$ so that Public Relations has a positive relationship with Brand Equity. This means that public relations affect positively on the brand equity of a product. Public Relations conducted by PT. Hasjrat Abadi Gorontalo Branch has been effective and efficient in increasing sales of Toyota Calya car products. 


\section{T Test and F Test}

\section{Pearson Correlation}

The Relationship of Pearson Correlation Advertising, Sales Promotion, Events and Public Relations to Brand Equity

\begin{tabular}{|c|c|c|}
\hline Variable & Pearson Correlation & Sig. \\
\hline Advertising & 0,208 & 0,029 \\
\hline Sales Promotion & 0,749 & 0,000 \\
\hline Events & 0,671 & 0,000 \\
\hline Public Relations & 0,607 & 0,000 \\
\hline
\end{tabular}

it can be concluded that each of the variables above shows that a positive and significant relationship with the following details:

- Pearson Correlation value for Advertising variable is 0.208 and Sig. $0.029<0.05$ shows that the relationship between Advertising with brand equity is weak, which means that advertising has a weak relationship with brand equity of a Toyota Calya car product.

- Pearson Correlation Value Promotion variable is 0.749 and Sig. $0,000<0.05$ shows that the relationship between sales promotion with strong brand equity means that sales promotion has a strong relationship to the brand equity of a Toyota Calya car product.

- Pearson Correlation Event variable value 0.671 and Sig. $0,000<0.05$ indicates that the relationship between the event / event with strong brand equity means that the event / event has a strong relationship to the brand equity of a Toyota Calya car product.

- Pearson Correlation value of Public Relations variable is 0.607 and Sig. $0,000<0.05$ shows that the relationship between public relations with strong brand equity means that public relations have a strong relationship to the brand equity of a Toyota Calya car product.

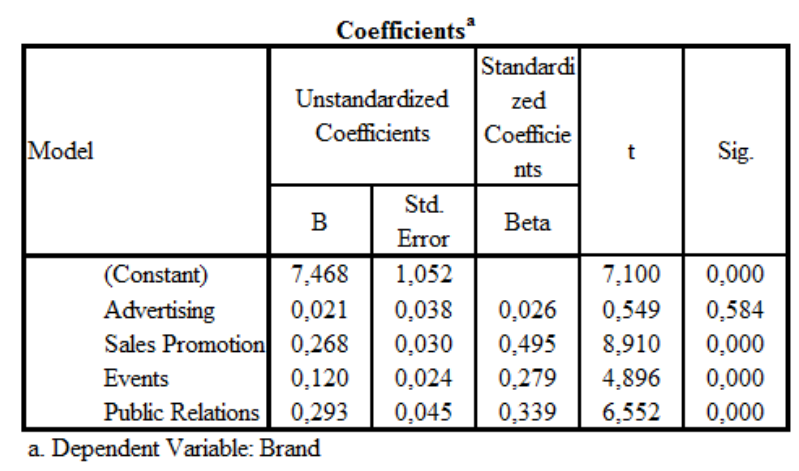

Advertising variables, sales promotions, events and public relations to brand equity can be summarized as follows:

- Advertising variable has a calculated $t$ value of $0.549<1.982 \mathrm{t}$ table and a Sig. of $0.584>0.05$. This means that advertising has a positive and insignificant effect on brand equity so the first hypothesis (H1): Does advertising have a significant effect on brand equity

- Sales promotion variable has a calculated t value of $8.549>1.982 \mathrm{t}$ table and Sig. at $0,000<0.05$. This means that sales promotion has a positive and significant effect on brand equity so that the second hypothesis (H2): Does sales promotion have a significant effect on brand equity.

- Event Variable has a calculated value of $4.896>$ $1.982 \mathrm{t}$ table and Sig. at $0,000<0.05$. This means that the event has a positive and significant effect on brand equity so that the third Hypothesis (H3): Does the event / event have a significant effect on brand equity.

- Variable Public relations has a calculated t value of $6.552>1.982 \mathrm{t}$ table and the value of Sig. at $0,000<0.05$. This means that community relations have a positive and significant effect on brand equity so that the fourth hypothesis (H4): Does community relations have a significant effect on brand equity. 


\begin{tabular}{|c|c|c|c|c|c|}
\hline \multicolumn{6}{|c|}{ ANOVA $^{\mathrm{a}}$} \\
\hline Model & $\begin{array}{l}\text { Sum of } \\
\text { Squares }\end{array}$ & $\mathrm{df}$ & $\begin{array}{l}\text { Mean } \\
\text { Square }\end{array}$ & $\mathrm{F}$ & Sig. \\
\hline Regression & 37,228 & 4 & 9,307 & 87,69 &, $000^{b}$ \\
\hline 1 Residual & 11,144 & 105 & 0,106 & & \\
\hline Total & 48,373 & 109 & & & \\
\hline \multicolumn{6}{|c|}{ a. Dependent Variable: Brand } \\
\hline \multicolumn{6}{|c|}{ b. Predictors: (Constant), Public Relations, Advertising, Sales promotion, } \\
\hline Events & & & & & \\
\hline
\end{tabular}

Variables Advertising, sales promotions, events and public relations to brand equity can be concluded that the calculated $\mathrm{F}$ value $87.690>2.46 \mathrm{~F}$ table, then advertising, sales promotion, events and public relations have a positive and significant effect simultaneously on equity brand. Then the fifth hypothesis (H5): Does advertising, sales promotion, events and public relations simultaneously influence brand equity.

\section{Determination Coefficient Test}

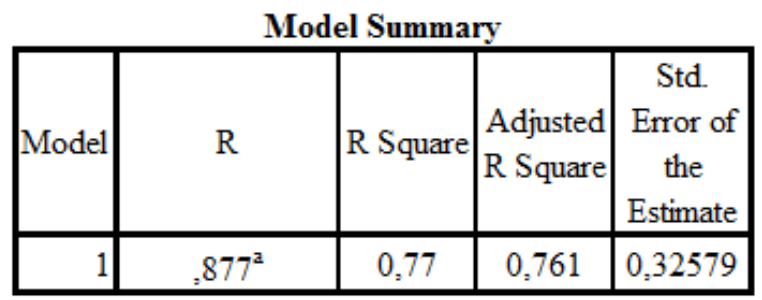

a. Predictors: (Constant), Public Relations, Advertising,

Sales promotion, Events

The results of the coefficient of determination obtained Adjusted R square coefficient of 0.761 or $76.1 \%$. Then it can be concluded that $76.1 \%$ brand equity can be explained by advertising, sales promotion, events and public relations and the remaining $23.9 \%$ is explained by other causes beyond this variable.

\section{v. CONCLUSION}

The results of the analysis and discussion above, it can be concluded as follows:
- Advertisements conducted by PT Hasjrat Abadi Gorontalo Branch have a positive but not significant effect on brand equity.

- Sales promotion conducted by PT Hasjrat Abadi Gorontalo Branch has a positive and significant effect on brand equity.

- Events carried out by PT Hasjrat Abadi Gorontalo Branch have a positive and significant effect on brand equity.

- Public relations carried out by PT Hasjrat Abadi Gorontalo Branch has a positive and significant effect on brand equity.

- The most dominant factor in the implementation of Integrated Marketing Communication conducted by PT Hasjrat Abadi Gorontalo Branch is sales promotion because it has a large impact in increasing sales of Toyota cars, especially Toyota Calya cars.Although a conclusion may review the main points of the paper, do not replicate the abstract as the conclusion. A conclusion might elaborate on the importance of the work or suggest applications and extensions. Authors are strongly encouraged not to call out.

\section{REFERENCES}

[1]. Aaker, David A. And Biel, Alexander L.. (2013). Brand Equity \& Advertising: Advertising's Role in Building Strong Brands. New York: Psychology Press.

[2]. Belch, George E. \& Michael A. Belch. (2012) Advertising and Promotion: AnIntegrated Marketing Communication Perspective. Global Edition. New York: McGraw-Hill.

[3]. Government Regulation (PP) No.41 of 2013 concerning Taxable Goods classified as Luxury in the form of Motorized Vehicles subject to Sales Tax on Luxury Goods. 
[4]. Kotler, Phillip and Kevin Lane Keller. (2016). Marketing Management 12th edition Volume 1 \& 2. Jakarta: PT. Index.

[5]. Kotler, Philip and Gary Armstrong. (2016). Principles of Marketing. Issue 13. Volume 1. Jakarta: Erlangga.

[6]. Lili Adi and Donni June (2017). Communication and Marketing Management. Bandung: Alfabeta.

[7]. Regulation of the Minister of Industry No.33 / M-IND / PER / 7/2013 concerning the Development of Energy-Saving and Affordable Four-Wheeled Motorized Vehicle Production.

\section{Cite this article as :}

Yudi Hamdani, Edy Prihantoro, "Effect of Integrated Marketing Communication on Brand Equity (Case Study of Toyota Calya Cars In Pt. Hasjrat Abadi Gorontalo Branch).", International Journal of Scientific Research in Science and Technology (IJSRST), Online ISSN : 2395-602X, Print ISSN : 23956011, Volume 7 Issue 4, pp. 96-103, July-August 2020. Available at doi : https://doi.org/10.32628/IJSRST1207426 Journal URL : http://ijsrst.com/IJSRST1207426 